\title{
THE EXAMINATION OF MARKETS OF ORGANIC FOODS
}

\author{
- \\ SZABÓ, Bernadett \\ GERGELY, Éva \\ TóTH, Fruzsina

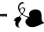 \\ University of Debrecen, Faculty of Economics, Institute of Management and Organization Sciences \\ H-4032 Debrecen, Böszörményi Street 138. \\ e-mail: szabo.bernadett@econ.unideb.hu
}

GI

Nowadays the consumption of organic foods has an outstanding importance from the aspects of health and environmental consciousness. In this study the habits of organic food consumption in Debrecen are examined by the help of a questionnaire-based survey and a personal interview. On the basis of our results the supply of organic foods in the local markets satisfies the requirement of the consumers, and this tendency is expected to be maintained for the future. The most popular products are vegetables, fruits, dairy products, meat and honey. Generally the consumers are very satisfied with these products. Most of the buyers choose organic foods not only because these products are healthy, but for the fact that they are aware of the environmentalfriendly technology by which the production happens. Consumers visiting the markets buy organic foods mainly at a weekly occasion, thus their consumption is conscious, and the healthy way of life is relevant for them. Many people do not know that there are such markets in Debrecen, in this way the promotion of these places is outstandingly important.

KEYWORDS: organic foods, market, environment consciousness, questionnaire

\section{INTRODUCTION}

In the last twenty years healthy diet has been playing a more and more important role, whose main reason is the fact that our environment and body have reached the limit of their tolerance in connection with coping with contaminations. The signs of these are reflected in natural disasters, as well as in the significant increase of diseases and death [5]. With this respect ecological farming has a great importance also in Hungary.

Ecological farming is a farming form neglecting synthetic fertilizer and pesticides and is based on natural biological cycles, organic fertilizers and biological plant protection. It can only be successful if people understand the operating principles of nature and they produce healthy food by co-operating with it. In this way the condition of the environment will not be deteriorated, thus it may be sustainable in the long run [4].

Nowadays ecological farming has a multidisciplinary feature, which is highlighted by Géza Márai and his co-authors: ecological farming includes agriculture, forestry, landscape management, food production of environmental friendly, renewable and special quality as well as rural development, which operates within strict regulations, under special control and qualification, furthermore with the need for active environmental conservation, health-care and change of life-style [9].

\section{LITERATURE REVIEW}

The online survey of NIELSEN MARKET RESEARCH COMPANY (2010) on purchasing organic foods is the biggest research of such a kind in the world [3]. The company carried out a survey in 54 countries, including Hungary. It was concluded that every eighth Hungarian consumer (13\%) buys organic foods, while this ratio is $35 \%$ in Europe. According to the results, $84 \%$ of the asked Hungarian consumers of organic foods think that these products are healthier, $70 \%$ think that they 
avoid pesticides and other poisons by choosing organic foods. More than $91 \%$ of the purchasers are influenced by the price when buying. One third of the respondents do not buy organic foods; the majority of those who buy organic foods, buy them in a monthly and weekly occasion [7]. On the basis of the data of a previous examination $35 \%$ of the respondents consume organic foods at least on a monthly basis, the regular consumers take up only $20 \%$ of the respondents [2].

Today from the aspects of health and environmental consciousness the consumption of organic foods has a great significance [7]. Motivations for consuming organic foods as well as the effect of personal values were examined among students in one of our previous research studies [1]. The respondents considered organic foods healthier, of higher quality, more environmentally friendly and tastier than conventional foods. Altogether the respondents had positive attitudes towards organic foods. Consuming organic foods for the sake of fashion or prestige was not typical. The most important motivation for consuming organic foods was maintaining the health. The biggest blocking factor of the consumption was the high price of organic foods. The facts that people do not believe in the production method and there are only few bio shops moderately hinder the organic consumption [1].

\section{Material and Method}

In this study our objective is to reveal the consumption habits of the city dwellers in Debrecen relating to organic foods. We carried out a questionnaire-based survey and connected information on the aim of starting consuming organic foods, on purchased products and on the frequency of purchasing. Our further aim was to investigate the price-sensitivity of the consumers. Our survey took place in four bio markets in Debrecen and happened with personal interviews.

The questionnaire consists of two parts. The first part relates to the demographic characteristics of the answerers concerning sex, age, education and income status. The second part of the questionnaire contains questions in connection with the purchase and consumption of organic foods. Altogether 100 consumers were asked.

The characteristics of the sample of the consumers are the following: $33 \%$ of the respondents are men, while $67 \%$ are women. Regarding the age structure of the respondents, $76 \%$ of the asked consumers belong to the 18 to 59 age group, while the respondents above 60 years represent $24 \%$. This ratio is in harmony with the results of the previous research studies, which proved that people between 18 and 59 years form the major consumer basis, from which people between 20 to 30 years and 40 to 50 years are dominant [6]. Examining the distribution of the respondents relating to education, $50 \%$ of the asked consumers have secondary education, while $45 \%$ of the consumers have diploma with a college or university degree. With respect to the income categories of the respondents, $9 \%$ of them live near the subsistence level. $61 \%$ of the asked people belong to the lower middle class, 30\% of them classified themselves as people belonging to the upper middle class.

In order to gain more detailed information on the operation of the markets of organic foods, a personal interview was carried out with the general manager of the Bio Yard Non-Profit Association (Bioudvar Debrecen) and three units of Producers' Yard (Termelői Udvar Debrecen) regarding the establishment of the market, products, prices and demand-supply conditions.

\section{RESULTS}

In the first part of this chapter we are going to detail the results of our survey among consumers of organic foods in Debrecen, then the characteristics of the local organic food market is introduced on the basis of the personal interview.

\subsection{Survey among Consumers of Organic Foods in Debrecen}

Regarding the sex distribution of the whole sample, the role of women $(67 \%)$ has a basic significance in purchasing foodstuffs. The ratio of female respondents between 18 to 59 years is $51 \%$, while only $25 \%$ of the male answerers belong to this age group. The ratio of the asked women above 60 years of age is twice as high (16\%) as in the case of men (8\%). The majority (55\%) of the answerers purchase organic foods on a weekly basis, while $19 \%$ buy such products several times a week, which means that healthy diet is important for most of the respondents, and they strive to purchase any organic food as frequently as possible. One quarter of the asked persons purchase and consume organic foods monthly. Half of those who buy organic foods on a weekly basis have secondary education, while the other part of these respondents have with a diploma. They are mainly women belong to the 
lower middle class and to the age group of 18 to 59 years.

Regarding the satisfaction of the respondents with organic foods the answerers could sign their answers on a scale ranging from 1 to 5 , where 1 meant the answer "not at all", while 5 indicated the answer "very satisfied". $63 \%$ of the respondents were very satisfied with the purchased products, $30 \%$ of them marked their answers with 4 , and $7 \%$ reflected their satisfaction with 3 . The mean is 4.56 , the standard deviation is 0.6247 . When examining this satisfaction according to sexes, ages, education and income categories, there was not any significant difference detected in the answers except for respondents belonging to the upper middle class whose ratio was more significant in answering " 3 ".

Regarding the products regularly purchased and consumed (Figure 1), the purchase of vegetables and fruits is dominant, as $83 \%$ of the asked consumers chose this product group. This is followed by the purchase of dairy products with $62 \%$. Bread and pastries as well as meat are equally important for the consumers and stand at the third place with $43 \% .35 \%$ of the respondents consume organic bio-honey and 23\% signed the purchase of juices, syrups and beverages. Naturally other products are bought as well, for example eggs, seeds, pickles etc.

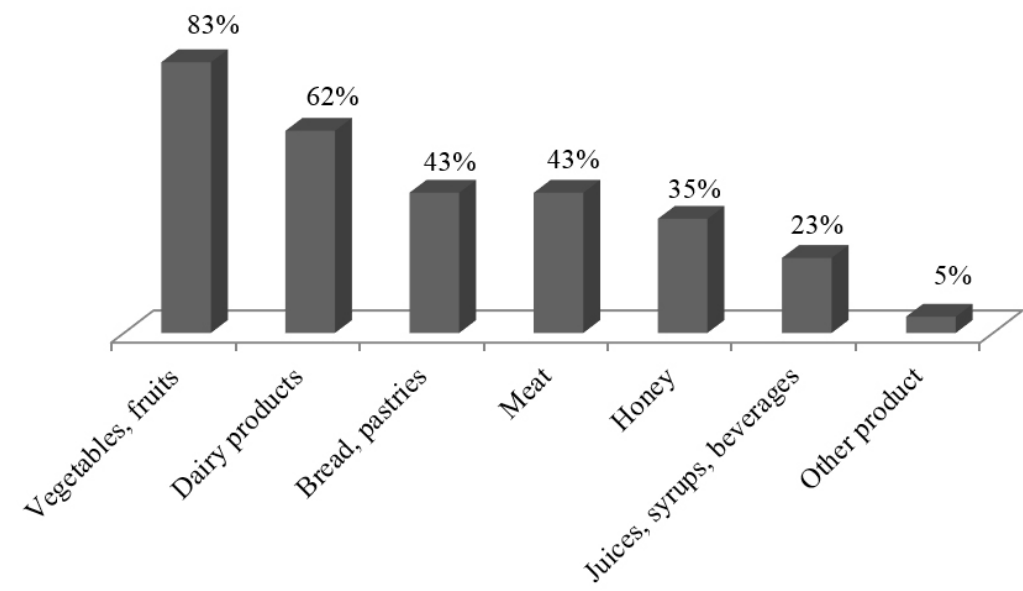

The Distribution of the Purchased Organic Products

A similar result is reflected when the answers are examined according to sexes and ages. Regarding the education and the income status, respondents who did not finish the primary school or live near the subsistence level do not spend on honey or bread and pastries, and they prefer buying meat and dairy products to vegetables or fruits.

We examined how much money the respondents spend on organic foods in a month. The ratio of the answers is almost the same. One third of the respondents spend less than 5000 HUF. $38 \%$ of the answerers spend on organic foods between 5000 and 10000 HUF, while $24 \%$ within an interval of 10000 and 30000 HUF in a given month. It turned out of the survey that there were consumers who were willing to pay more than 30000 HUF for organic foods in a month. Their ratio was $6 \%$. The majority of the respondents above 60 years of age, however, spend less than 5000 HUF in a month for these kinds of products, which is also true for both people having no education or living near the subsistence level.

On the basis of our examination, in the markets of organic foods the willingness to pay a surplus of 15 to $20 \%$ is typical. Pensioners, or respondents living near the subsistence level can afford to pay only $5 \%$ surplus for organic foods. Only $2 \%$ of the answerers with having a diploma and belonging to the upper middle class said that was no matter the price they purchased organic foods on. 
$26 \%$ of the asked persons purchase and consume organic products because these are healthier than the conventional ones (Figure 2). Moreover, besides this, a significant part of the asked consumers (67\%) buy such products as they are aware of the fact that the production of these products happens with environmental friendly technology. The modifying influence of advertisement is not typical among the answerers. $6 \%$ of them consume organic foods because of other reasons, such as food allergy or any disease, but some of them think that the taste of these foodstuffs is more delicious than that of conventional products. No one of the answerers consume these kinds of products only because of the fact that the consumption of organic foods is considered to be as the trend of the 21st Century. There was not any significant difference in the answers according to sexes, ages, education and income categories.

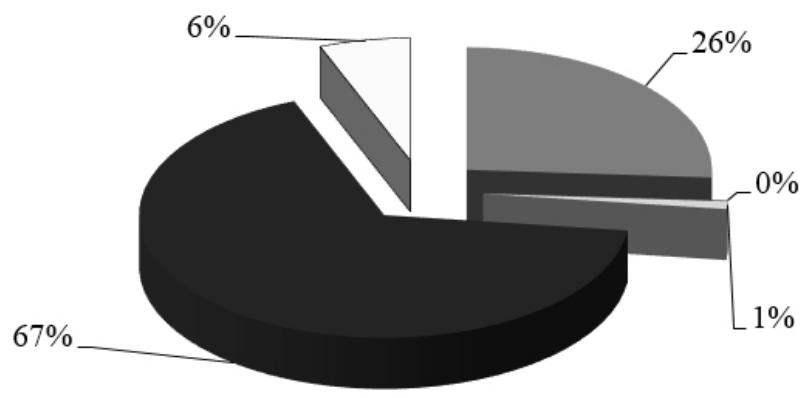

n They are healthier than the conventional products

It is the trend of the 21 st Century

Influenced by advertisements on different organic foods

- They are not only healthy but their production is environmental-friendly

口Other reason

The Reasons of Purchasing and Consuming Organic Foods

FIG 2

Source: own survey

\subsection{Introducing the Characteristics of Bio Yard Market}

The Bio Yard was formed in Debrecen in August 2003 in order to save the environment and the health of the next generation. The sellers come from the Northern Great Plain Region, mainly from Balmazújváros. Most of the buyers live in Debrecen, but also consumers from Mátészalka or Oradea may come to visit the market. At the beginning there were 8 to 10 sellers in the market. The sellers changed, but their number remained the same. Presently there are 8 sellers in the market who sell their own organic foods. Regarding the supply, they serve products for the consumers according to the season. It is obvious that the supply is not so wide as it is in the big market (for example one cannot buy tomato or grapes during the winter time), but the consumers can find the seasonal products in the market. The tendency of the prices is a very cardinal issue of ecological farming. As it has been mentioned before the selling price of these products is higher by 100 to $200 \%$ than that of conventional products. It is an eternal debate not only among the buyers and the sellers, but also within "eco circles". It is obvious that this farming form has a high labor need, and it needs daily spraying without chemicals, which all have to be compensated in the price.

Relating to the demand, there are 80 to 100 people who always visit the market on Saturdays, which reflects the fact that there is a fix demand for organic foods and people may afford to buy them. Every seller should have a certification of any of the controlling organizations. One of the controllers lives near Debrecen, furthermore, controllers from the plant protection station may also visit them anytime, in this way the sellers are under strict view and can be controlled anytime. The general manager of the market did not get any subsidy for the establishment of the Bio Yard. 


\section{Conclusions and RECOMMENDATIONS}

According to the interview the organic foods in the local markets satisfy the requirements of the surveyed consumers, and this tendency is expected to be maintained for the future. The seasonal products served by the sellers are in harmony with the products looked for by the consumers. The most popular products are vegetables, fruits, dairy products, meat and honey, but naturally other products are also available for the consumers. The survey proved the fact that most of the respondents are very satisfied with these products.

Many respondents choose organic foods not only because they are healthy, but also for the fact that they are aware of the environmental-friendly technology by which the production happens. In this way, they serve not only their own health and that of the next generation, but they contribute to ensuring the sustainability of the land as well.

It turned out of the survey that consumers visiting the markets buy organic foods mainly on a weekly occasion, thus their consumption is conscious and they consider healthy lifestyle as being relevant. As these markets are open 7 days of the week, and the majority of the producers' yard are reachable also in the afternoons, the organic foods can be purchased easily and regularly. The price sensitivity of the respondents can be considered extremely low. The majority of the answerers are willing to pay a surplus of 15 to $20 \%$ for organic foods compared to conventional products. In the case of organic foods the higher labor demand and the daily spraying without any chemicals have to be paid for. This reflects a great anomaly relating to the small ratio of willingness to pay a surplus and to the higher prices of organic foods by 100 to $200 \%$ than that of conventional products, which anomaly has to be solved in the future.

The major part of the consumers favors purchasing from bio-markets as well as from producers [8]. It gives an opportunity for building connections between consumers and sellers, thus the consumers may get to know the producers and their products better, while for the sellers it is important that more and more people should know about their products.
Many people do not know that there are such markets in Debrecen [8], in this way their promotion is necessary. It is important to inform the society in a proper way by marketing activities such as advertisements in media, organizing different events such as performances, fairs and open days in order to increase the demand. An initiative, would be useful in which the producers would collaborate with each other in order to promote and sell their products through a webpage.

As the ecological label of the European Union is not compulsory for not pre-packaged products, the majority of organic foods in the market do not have such a label. By using this, the products could be promoted and the consumers would be aware of the origin and the quality of the products, thus they would purchase them with a greater confidence. The success of using this label depends on the facts that whether the utilization of these labels has a real impact on the increase of purchasing these products and to what rate, whether the present and the potential consumers would be willing to pay a surplus for the labeled products, and whether all these surpluses would cover the extra costs relating to the label. If so, then all these would contribute to expanding the consumer base, to establishing a conscious and healthy diet as well as to reforming the consumers' habits.

\section{SUMMARY}

The consumption habits of organic foods in Debrecen were introduced in this paper. The most important action to be taken is an intensive marketing activity, as well as wide-spread information for the consumers for the sake of the promotion of organic foods. As for us, ecological farming has a future in Hungary, which is based on our data and information collected and on our experience gained during the survey. The interest of the consumers on the one hand is the fact that they can consume products which are basically healthy, but on the other hand their production of which is not harmful to the nature and contributes to sustainability. By realizing this, the demand for is expected to increase organic foods. 


\section{REFERENCES}

[1] Gergely É. - Szabó B.: Consumer Attitudes, Motivations and Misbeliefs Relating to Organic Foods. In: Élelmiszer, Táplálkozás és Marketing. 2013. 9 (2) 33-37.

[2] Lengyel P.: „Biomarketing” A bioélelmiszerpiac bemutatása, a kategória iránti kereslet alakulása a fiatal felnőttek körében, Budapesti Gazdasági Főiskola, Szakdolgozat, 2008.

[3] Nielsen Market Research Company: Bioterméket csak minden nyolcadik magyar szokott vásárolni. 2010. URL: http:// hu.nielsen.com/site/20100819.shtml (Time of downloading: 8. September. 2014.)

[4] Radics L.: Ökológiai gazdálkodás a felsőfokú szakképzés hallgatói számára. Szaktudás Kiadó Ház, Budapest, 2006. 13.
[5] Sárközy P. - Seléndy Sz.: Biogazda I., Budapest, 1993. 242.

[6] Szolnoki Gyózőné: Az ökológiai marketing egyes sajátosságai a biogazdálkodásban. DATE, Debrecen, 1996. 15.

[7] Tóth H.: Innováció az életmódban - avagy a hosszú élet titka. ECOSTAT Kormányzati Gazdaság- és Társadalom-stratégiai Kutató Intézet Múhely. 2009. július

[8] Tóth F.: Az ökológiai gazdálkodás helyzete és az ökotermékek megítélése fogyasztói szemszögből. DE GVK, Debrecen, 2013. 44.

[9] www.zeus.nyf.hu: URL: http://zeus.nyf. hu/ tkgt/okse/okolgazd/oklgazd201103.pdf. (Time of downloading: 8. September 2014.)

\section{JEGYZETEK $*$ NOTES}

